\title{
Knowledge about menstrual cup and its usage among medical students
}

\author{
Manorama Eti, Shreya M. S.*, Sailakshmi M. P. A.
}

Department of Obstetrics and Gynecology, RRMCH, Bangalore, Karnataka, India

Received: 23 September 2019

Accepted: 06 November 2019

\section{*Correspondence:}

Dr. Shreya M. S.,

E-mail: drmanoramaeti19@yahoo.in

Copyright: ( $)$ the author(s), publisher and licensee Medip Academy. This is an open-access article distributed under the terms of the Creative Commons Attribution Non-Commercial License, which permits unrestricted non-commercial use, distribution, and reproduction in any medium, provided the original work is properly cited.

\begin{abstract}
Background: Menstrual cups have been available for decades, but their use in India is limited because of lack of awareness and popularity of sanitary pads. Since they are reusable, they reduce solid waste and are environment friendly. The need of the hour is education, awareness, and availability of the eco-friendly practices when it comes to managing menstrual waste effectively. Once that is taken care of, it will be easy for anyone to make a green switch.

Methods: A total 400 medical undergraduate students (females) were given a questionnaire. The objective of the study was to assess knowledge about the menstrual cup among students.

Results: Among 400 medical students, 28(7\%) of them dint know what a menstrual cup was! 262(70.4\%) students were for usage of menstrual cup in virgins. There was no clear picture among students regarding material used in cup manufacture, its emptying time and sterilisation technique. Among 372 students, none of them used a menstrual cup.

Conclusions: All the students in the study used sanitary pads, owing to its popularity and promotion. There was lack of awareness about the cup. So, we conclude that menstrual cup needs promotion in India. To boost the adoption rate of menstrual cups, youth should be targeted, who are more open to the idea of environment-friendly products. The Government must conduct awareness programs in the rural areas and work constantly spreading the message across all socio-economic sectors so that we can make the dream of a "pad free country", a reality soon.
\end{abstract}

Keywords: Awareness, Medical students, Menstrual cup

\section{INTRODUCTION}

A menstrual cup is a device that is inserted into the vagina during menstruation. It acts by collecting menstrual fluid. They are usually made of flexible medical grade silicone and shaped like a bell with a stem. The stem helps for easy insertion and removal. The bell shape of the cup helps it to get sealed against the vaginal walls below the cervix. The cup has to be removed, emptied, rinsed and reinserted depending on the amount of the flow (usually every 6-12 hours).

\section{Need for promoting the use of menstrual cup in India}

Menstrual cups greatly reduce the waste generated from menstrual cycles as it is reusable, unlike sanitary pads and tampons. Hence, it is more eco-friendly. Since it can be used for five or more years, its more economical too. Menstrual Hygiene Management (MHM) is an integral part of the Swachh Bharat Mission Guidelines (SBM-G). ${ }^{1}$ The MHM Guideline (December 2015) is issued by the Ministry of Drinking Water and Sanitation to support all adolescent girls and women. According to it, the sanitary waste should be wrapped in leak proof pouches provided by producer and should be disposed with dry waste at the time of door to door collection.

According to State of India's Environment 2019 Survey, the Menstrual Hygiene Alliance of India (MHAI) has approximated that there are 336 million menstruating women in India, of which 36 per cent use disposable sanitary napkins - that totals to 121 million women. ${ }^{2}$ This 
implies that India has 12.3 billion disposable sanitary napkins to take care of every year, majority of which are not biodegradable/compostable. According to the Solid Waste Management (SWM) Rules 2016, the items contaminated with blood and body fluids, including cotton, dressings, soiled plaster casts, lines and bedding, are bio-medical waste and should be incinerated, autoclaved or microwaved to destroy pathogens. ${ }^{1}$ SWM Rules 2016 suggest that all menstrual waste should be sent to one of the 215 large scale common bio-medical waste incinerators that exist across the country. However, this requires organised segregation, collection and transportation of menstrual and other sanitary waste on a large scale. No viable models for this have been formulated or implemented till now. While incineration is being proposed as a solution, at present it is still not practiced. Let us see what is happening in India practically.

Sanitary pad disposal in India is still a concern. Women and girls feel awkward if anybody sees them disposing a pad. So, they land up flushing them in toilet without knowing the consequences of choking. ${ }^{3}$ Used sanitary pads when thrown in open fields end up in landfill and can be breeding grounds for a lot of infectious microbes and takes hundreds of years to degrade. The plastic used in sanitary napkins, is non-biodegradable, and is not only harmful for health, but also has negative consequences on the environment. Waste pickers separate out soiled napkins from recyclable items by hand, exposing themselves to micro-organisms like E.Coli, salmonella, staphylococcus, HIV and pathogens that cause hepatitis and tetanus.

Why should a menstrual cup be used then? As already discussed above, apart from it being eco-friendly, it is also cost-effective, with a lifetime up to 10 years without any health hazards. Less chances of vaginal irritation and infections. Since the cup holds the menstrual blood at the cervix, it prevents the blood from flowing through the vaginal canal, allowing for hassle-free sexual intercourse. Extremely travel-friendly and no need to be changed often. Also does not emit odour.

\section{Need for the study}

If there are so many advantages of menstrual cup over sanitary pads, then why is it still not been so popular? Probably because of lack of knowledge and the menstrual cup not been promoted as much as it should have been, especially in a country like India. Also, because India is still an unreasonably conservative country. A menstrual cup is inserted into the vagina, while a menstrual pad isn't. So, people think that using a cup in unmarried girls might result in loss of virginity. Since we follow western culture, the idea of use and throw is becoming more a norm than thinking in a realistic way! Due to the lack of promotion and popularity of sanitary pads even educated ones have meagre knowledge about menstrual cup. So, the objective of the study was to assess knowledge about Menstrual Cup and its usage among student population. .

\section{METHODS}

400 undergraduate medical students belonging to second, third and final year MBBS of Rajarajeswari Medical College and Hospital were included in the study population. Boys were excluded from the study. All the girls were made to assemble in a classroom and a questionnaire was handed over to them. Fifteen minutes time was given to complete it.

Since we wanted to know the Medical student's knowledge about the Cup, simple questions regarding the details of the cup and its usage were printed in the questionnaire. Most of the questions were in the form of MCQs (Multiple Choice Questions).

Are you aware of menstrual cup? If Yes, to continue with the below questions.

Is menstrual cup a safe device?

Can it be used in virgins?

Mechanism of action of menstrual cup

Material with which the menstrual cup is made up of?

How frequently the menstrual cup should be emptied?

Mode of sterilization of menstrual cup

Is menstrual cup associated with TSS (Toxic Shock Syndrome)?

Can the cup be used during postpartum $(<6$ weeks of delivery)?

Can menstrual cup be used while swimming and bathing?

Can it be used as a method of contraception?

The questionnaire ended with, whether they used a menstrual cup anytime and what was their experience. If not used, then the reason behind it.

\section{Statistical analysis}

Data was entered into Microsoft excel sheet and analysed into descriptive statistics like percentages.

\section{RESULTS}

Out of 400 medical students who took part in the study, $28(7 \%)$ of them discontinued with the questionnaire stating that they were not aware of what a menstrual cup was! Rest 372 (93\%) students completed the 
questionnaire. $313(84.13 \%)$ students were for usage of menstrual cup in virgins. 368 (99\%) knew its mechanism of action that it acts by collecting menstrual blood. There was no clear picture among students regarding material used in cup manufacture, its emptying time, sterilisation technique and its association with toxic shock syndrome. $224(60.2 \%)$ students said yes for its usage during postpartum ( $<6$ weeks), which is usually not done. 20 $(5.3 \%)$ students were having a wrong notion about cup usage as a contraceptive device. Finally, among 372 students, none of them used a menstrual cup.

\section{DISCUSSION}

Among 344 (92.47\%) students said menstrual cup to be a safe device (Table 1). In a study done by Juma $\mathrm{J}$ et al, wherein safety of menstrual cup was evaluated among primary school girls, also found that cups are safe with no health harms. ${ }^{4}$

Table 1: Knowledge of students about menstrual cup as a safe device and its use in virgins.

\begin{tabular}{|lll|}
\hline $\begin{array}{l}\text { Is menstrual cup a } \\
\text { safe device? }\end{array}$ & $344(92.47 \%)$ & $28(7.52 \%)$ \\
\hline $\begin{array}{l}\text { Can it be used by } \\
\text { virgins? }\end{array}$ & $313(84.13 \%)$ & $59(15.86 \%)$ \\
\hline
\end{tabular}

A total $313(84.13 \%)$ students were for usage of menstrual cup in virgins. Whereas $59(15.86 \%)$ students were of the opinion that it cannot be used in virgins, which authors all know is a myth. Virgins and young girls have vaginal muscles that tend to be tighter, which can make insertion a bit more difficult. Girls should be educated regarding this that virginity should not be an obstacle for cup usage.

Table 2: Knowledge of students about mechanism of action of cup.

\begin{tabular}{|lll|}
\hline $\begin{array}{l}\text { Mechanism of action } \\
\text { of menstrual cup }\end{array}$ & Collection & Absorption \\
\hline $\mathrm{N}=372$ & $368(98.92 \%)$ & $4(1.07 \%)$ \\
\hline
\end{tabular}

When asked about mechanism of action of menstrual cup, majority of them, $368(99 \%)$ knew that it acts by collecting menstrual blood (Table 2).

Authors wanted to know if students knew anything about the material used in cup manufacturing. Authors were surprised to know that $76(20.4 \%)$ of them had no idea about the material with which the cup was manufactured. Only $80(21.5 \%)$ of them knew that cups could be made from TPE (thermoplastic elastomer), silicon, latex and natural gum rubber. 104 (27.9\%) of them thought cups are manufactured only using silicone. Rest $30 \%$ of them voted individually for TPE, latex and rubber. This shows that students dint has a clear picture about

the material used in cup manufacturing (Table 3). The students were asked on how frequently the cup has to be emptied assuming the person to have normal menstrual flow. Only $171(45.9 \%)$ of them knew it correctly as 6 to 12 hours. $193(51.8 \%)$ of them had no idea regarding this (Table 4)

Table 3: Knowledge of students about material used in manufacturing the cup.

\begin{tabular}{|lccllll|}
\hline $\begin{array}{l}\text { Material used in } \\
\text { manufacturing the cup }\end{array}$ & Silicone & TPE & $\begin{array}{l}\text { Natural gum } \\
\text { rubber }\end{array}$ & $\begin{array}{l}\text { Latex } \\
\mathrm{N}=372\end{array}$ & $\begin{array}{l}\text { All of the } \\
\text { above }\end{array}$ & No idea \\
\hline
\end{tabular}

Table 4: Knowledge of students about emptying time of the cup.

\begin{tabular}{|c|c|c|c|}
\hline Emptying time of the cup (assuming it to be normal menstrual flow) & 1-2 hours & 6-12 hours & No idea \\
\hline $\mathrm{N}=372$ & $8(2.1 \%)$ & $171(45.96 \%)$ & $193(51.8 \%)$ \\
\hline
\end{tabular}

Table 5: Knowledge of students about sterilisation of menstrual cup.

\begin{tabular}{|llllll|}
\hline $\begin{array}{l}\text { Sterilisation } \\
\text { of the cup }\end{array}$ & $\begin{array}{l}\text { Washing under running } \\
\text { water }\end{array}$ & Boiling & Using microwave & All of the above & No idea \\
\hline $\mathrm{N}=372$ & $162(43.5 \%)$ & $106(28.4 \%)$ & $0(0 \%)$ & $50(13.4 \%)$ & $54(14.5 \%)$ \\
\hline
\end{tabular}

Sterilization of the cup is the most important aspect in its usage because if not done properly could lead to development of infections. $162(43.5 \%)$ of them told it could be done by washing under running water. 106
$(28.4 \%)$ of them were for boiling. None of them voted for sterilization with microwave. $50(13.4 \%)$ of them were of the opinion, that it could be done by all methods like washing, microwave and boiling (Table 5). 
Coming to menstrual cup usage and toxic shock syndrome (TSS), 144 (38.70\%) of them were of the belief that there could be risk of getting infected with the cup usage. While $162(43.5 \%)$ of them found no association.

In an article published in the year 2015 by Mitchell MA et al, only one case of confirmed TSS was found in association with usage of cup. ${ }^{5}$ Study done by Nonfoux L et al, concluded that though increase of $S$. aureus and toxin production was noted in menstrual cup, in in vitro system, practically this could be avoided by using a small sized cup and boiling of the cup in between the cycles. ${ }^{6}$ Though there might be slight risk associated, none of them discommend its use, as the risk could be overcome by following hygienic practices and by not leaving the cup inside the vagina for too long (Table 6).

Table 6: Knowledge of students about menstrual cup and its association with TSS.

\begin{tabular}{|lll|l|}
\hline Association with toxic shock syndrome & Yes & No & No idea \\
\hline $\mathrm{N}=372$ & $144(38.70 \%)$ & $162(43.54 \%)$ & $66(17.74 \%)$ \\
\hline
\end{tabular}

Table 7: Knowledge of students about menstrual cup usage during postpartum ( $<6$ weeks of delivery).

\begin{tabular}{|lll|}
\hline Usage during postpartum period (<6 weeks) & Yes & No \\
\hline $\mathrm{N}=372$ & $224(60.2 \%)$ & $148(39.78 \%)$ \\
\hline
\end{tabular}

A total $224(60.2 \%)$ students said yes for its usage during postpartum. Its usage is usually not recommended until 6 weeks postpartum because it can introduce infection as the tissues are not fully healed especially in case of normal delivery. Also, because the position and shape of the cervix takes time to revert back (Table 7).

Table 8: Number of students using menstrual cup and sanitary pads in the study.

\section{Number of students using Menstrual cup $\quad 0$}

Number of students using sanitary pads 372

Regarding usage of cup during swimming, majority of them $304(81.7 \%)$ knew it could be used, and had an advantage over sanitary pads. $20(5.3 \%)$ students were having a wrong notion about cup usage as a contraceptive device. They thought it could be used as a contraceptive device!

Finally, among 372 students who completed the questionnaire, none of them had used a menstrual cup (Table 8). $59(15.8 \%)$ of them attributed it for cultural reasons, wherein they were not sure it could be used by virgins. $28(7.5 \%)$ of them were not using as the procedure of inserting and removing the cup was not familiar. $285(76.6 \%)$ said they dint look into other options as they were comfortable with sanitary pads.

This shows that, students are not aware of the benefits of menstrual cup over sanitary pads. Menstrual cup is not so a popular device in India and it is not used by people for various reasons. That is why, students dint have a clear picture regarding material used in cup manufacturing, its sterilization technique, association with TSS and its use in postpartum period.
In a developing country like India, women need effective, safe and affordable menstrual products that are also eco-friendly. Menstrual cup is one such alternative! It is found that acceptance of the cup required familiarization over several menstrual cycles and peer support improved acceptance in developing countries. ${ }^{7}$ Menstrual cups are safe devices and are used internationally. They have to be promoted in India because they have the potential to be a good solution to menstrual management by being eco-friendly and economical. ${ }^{8}$ One such project done in India this year is "Project Thinkal" launched by Alappuzha Municipality in Kerala where they encouraged usage of menstrual cups instead of non-biodegradable sanitary pads. ${ }^{9}$ Cups were distributed for free to the female residents during the first phase.

\section{CONCLUSION}

All the students in the study used sanitary pads, owing to its popularity and promotion. There was lack of awareness of the benefits of the cup over sanitary pads. Menstrual cups have to be made popular in India, which is a developing country and lacks proper solid waste management. To boost the adoption rate of menstrual cups, youth should be targeted, who are more open to the idea of environment-friendly products. The Government must conduct awareness programs in the rural areas and work constantly spreading awareness across all socioeconomic sectors so that authors can make the dream of a "pad free country" a reality soon.

Funding: No funding sources

Conflict of interest: None declared

Ethical approval: The study was approved by the Institutional Ethics Committee 


\section{REFERENCES}

1. Guidelines for management of sanitary waste. Available at: https://kspcb.gov.in > Sanitary Waste_. Accessed on $06^{\text {th }}$ August 2019.

2. The mammoth task of managing menstrual waste in India. Available at: https://www.downtoearth.org.in > blog > health > the-mammoth-task-of-m. Accessed on $27^{\text {th }}$ February 2019 .

3. Kaur R, Kaur K, Kaur R. Menstrual hygiene, management, and waste disposal: practices and challenges faced by girls/women of developing countries. J Envir Pub Health. 2018;2018.

4. Juma J, Nyothach E, Laserson KF, Oduor C, Arita L, Ouma $\mathrm{C}$, et al. Examining the safety of menstrual cups among rural primary school girls in western Kenya: observational studies nested in a randomised controlled feasibility study. BMJ Open. 2017;7(4):e015429.

5. Mitchell MA, Bisch S, Arntfield S, HosseiniMoghaddam SM. A confirmed case of toxic shock syndrome associated with the use of a menstrual cup. Canad J Infect Dis Med Microbiol. 2015;26(4):21820.

6. Nonfoux L, Chiaruzzi M, Badiou C, Baude J, Tristan A, Thioulouse $\mathbf{J}$, et al. Impact of currently marketed tampons and menstrual cups on Staphylococcus aureus growth and toxic shock syndrome toxin 1 production in vitro. Appl Environ Microbiol. 2018;84(12):e00351-18.

7. van Eijk AM, Zulaika G, Lenchner M, Mason L, Sivakami M, Nyothach E, et al. Menstrual cup use, leakage, acceptability, safety, and availability: a systematic review and meta-analysis. The Lancet Pub Health. 2019;4(8):e376-93.

8. Howard C, Rose CL, Trouton K, Stamm H, Marentette D, Kirkpatrick N, et al. FLOW (finding lasting options for women): multicentre randomized controlled trial comparing tampons with menstrual cups. Canad Fam Phy. 2011;57(6):e208-15.

9. Bechu S. A Kerala civic body is distributing 5,000 menstrual cups for free; here's why!. The New India. $2019 . \quad$ Available at: https://www.newindianexpress.com/good-news/2019 /jun/18/a-kerala-civic-body-is-distributing-5000menstrual-cups-for-free-heres-why-1991887.html. Accessed on $8^{\text {th }}$ July 2019.

Cite this article as: Eti M, Shreya MS, Sailakshmi MPA. Knowledge about menstrual cup and its usage among medical students. Int J Reprod Contracept Obstet Gynecol 2019;8:4966-70. 